\title{
Feminist Öznenin Toplumsalla Kuruluşunda Sinema-Ötekiyle Karşılaşma
}

\author{
Nüket Elpeze Ergeç*
}

$\ddot{O} z e t$

Bu çalışma, Türkiye'de "mahcup feminizm" kavramı ekseninde 1980'li yıllarn akademik feminist düşüncesinin sinemaya etkisine bakmayı amaçlayan bir girişimdir. Güçlü bir feminist sesin olmadiğg bu yıllar, akademide kadın sorunun araştırıldiğı ve sinemanın da değişim geçirdiği bir dönemdir. Özellikle kadınlara ve kadınlığa ilişkin meselelerin ele alındiğı kadın filmleri kategorisinin oluşmaya başlaması da bu döneme denk gelir. Feminist söylem çözümlemesi metnin içinde doğallaşarak görünmez olanve kendini metin aracılı̆̆ıyla yeniden üreten her türlü ideolojiyi ortaya çıkarır. Çalışmanın kavramsal çerçevesi Türkiye'deki feminist hareketin öncüllerinden Şirin Tekeli'nin güçlü bir feminist sesin olmamasın tanımlamakta kullandiğg "mahcup feminizm" terimi merkezinde oluşturulmuştur. Kavramsal çerçeve kurulurken dikkat edilen nokta fail olan öznenin değişimi dönüşümü ve kendini kurma biçimi olmuştur. Akademide Şirin Tekeli, Bir Yudum Sevgi (AtıfYilmaz, 1984) filmindeki Aygül, Videosinema dergisinde karşılaşılan Şengül'ün söylem düzeni içinde feminist özne olma biçimleri incelenmiştir. Çalışmada akademik yazın, popüler yazın ile sinema arasındaki kadın kimliğine ilişkin öznelerin karşılaşmaları, kucaklaşmaları, benzerlikler ve sınırlamaları saptanmış ve tartışılmıştır.

Anahtar kelimeler: Feminist Özne, Videosinema Dergisi, Bir Yudum Sevgi Filmi, Mahcup Feminizm

ORCID ID : https:/ / orcid.org/ 0000-0003-4591-7982

E-mail : nergec@gmail.com

DOI: 10.31122/sinefilozofi.514971

Geliş Tarihi - Recieved: 22.06.2020

Kabul Tarihi - Accepted: 05.10.2020 


\title{
In The Cinema Establishment of Feminist Subject with The Social- Encounter Others
}

\author{
Nüket Elpeze Ergeç*
}

\begin{abstract}
This study is aimed to look at the effect on movies of academic feminist thought 1980's in Turkey on the basis of the concept with "embarrassed feminism". There is no strong feminist voice in these years and the problems of women are being investigated in the academy. Cinema is also changing in these years. It is also during this period that the category of women's films, in which the issues concerning women and femininity are addressed, begins to emerge. Feminist discourse analysis reveals any ideology that has become invisible by naturalizing in the text. The conceptual framework of the study has been established in terms of "embarrassed feminism" that Tekeli was used to describe for the feminist movement there were weak feminist voices in Turkey. The point that was taken into consideration while establishing the conceptual framework was the change, transformation and self-assembly of the perpetrator. In the academy, Şirin Tekeli, Bir Yudum Sevgi (Atıf Yılmaz, 1984), Aygül in the film, Şengül, encountered in the Videosinema magazine, have examined the ways of being a feminist subject in the discourse order. In the study, the encounters, embraces, similarities and limitations of the subjects related to women's identity between academic literature, popular literature and cinema were determined and discussed.
\end{abstract}

Key words: Feminist Discourse, Videosinema Magazine, "Bir Yudum Sevgi" Film, Embarrassed feminism

ORCID ID : https:/ / orcid.org/ 0000-0003-4591-7982

E-mail : nergec@gmail.com

DOI: 10.31122/ sinefilozofi.514971

Geliş Tarihi - Recieved: 22.06.2020

Kabul Tarihi - Accepted: 05.10.2020 


\section{Giriş}

Feminizm ve sinema ilişkisi yeni değildir. Sinemada üretim sürecinde feminist dilin oluşması beklentisiyle kadın yönetmenler ayrı bir kategoride değerlendirilirken, kadın filmleri yapan erkek yönetmenlerin "kadın filmleri yönetmeni" (Atıf Yılmaz, Pedro Almadovar gibi) olarak nitelendirildiği görülür. Sinema ile feminizm ilişkisindeki araştırmalarda genel başlıkla, sinema dilindeki hegemonik ilişkiler incelenirken kadının cinselliği, kadının metalaşması, kadının sinemaya bakışı ya da sinemanın kadına bakışı temelinde toplumsal cinsiyet olgusunun kurgulanışının değerlendirilmesi (Kuhn, 1982, Mulvey, 1997, Smelik, 2008) ve sinemada kadın temsili gibi konuların ele alındığı görülür(Abisel, 2005, Kellner, 1996, Yılmaz, 2004 ve Wood 1992). Bu başlıklardan, sinemada kadın temsilinin, postyapısal yaklaşımla sinemanın erkeklerin psikolojik ihtiyacı için yapıldığı yorumunu yapan Mulvey (1997)'in temsil stratejilerinin arkasındaki düşünceye ulaşması bakımından önemlidir. Bu, sinemada erkek bakışının teorik analizi için ufuk açıcıdır. Ancak biraz daha geniş bir çerçeveden bakarak teorik feminist söylem üretiminin, sinemada toplumsal cinsiyet temsillerinin üretimi, kültürel pratiklerde kadın temsilleri ve gündelik hayattaki kadın deneyimlerinin toplumsal dinamik içinde ne kadar kesiştiği de önemsenmelidir. Buna dair çalışmalar da literatürde yer alır (Kuhn, 1982, Kırel, 2010). Zira sinema, pek çok konu gibi toplumsal cinsiyetin temsilinde önemli bir bellektir. Toplumu anlayabilmek ve sinemadaki karakterlerin evirilmesinin altında yatan düşüncelere ulaşılabilmesi için çok boyutlu ve çok katmanlı bakış için söylem çalışmaları önemli görülmelidir. Söylemin düzeninde merkeze metinler yerleştirilirken, söylemsel pratikler ve toplumsal pratikler nihayetinde feminist düşüncenin dolayımlanmasındaki süreçleri ortaya çıkarmakta bütüncül bir yapı arz eder. Çünkü bu yaklaşım, toplumsal üretim biçiminin bir aradalığını değerlendirme imkanı verir.

Günümüzde kadın kimliğine ilişkin söylemsel yapı, ayrılıkçı, sabitlenmiş ve önyargılı algılarla temellendiği görülür. Sara Ahmed'in (2017) dediği gibi kadının sabitlenmiş kimliği bir sorun olarak görülmezken çözümlemeye dahil girişimlerde anlaşılmaz hal alır. Birey ile toplum arasındaki ilişkilere yoğunlaşan ideoloji kuramları, dışsal toplumsal nesnelliğin öznel bireyde nasıl oluştuğunu inceler. İdeoloji gerçekte dişsal ve nesnel olmasına rağmen, özne tarafından üretilmeyen ama özneyi üretendir. İdeoloji, bu anlamların özne üzerinden nasıl harekete geçirildiği ile ilgilidir. Ancak ideoloji kuramı Post Marksist düşüncede Sancar'a göre (2014) yerini söylem kavramına bırakmıştır. Bu noktada ideolojinin işlevi yerine, ideolojik öznenin nasıl oluştuğuna dair süreçler önem kazanmaktadır. Söylemin çözümlenmesi toplumsal olanın yeni bir gözle anlaşılmasını sağlar. Söylem, anlamın dil içinde hareketi olup sözün toplumsallaşmasıdır. Söylem çözümlemesinin konusu sözün kime yöneldiği, ne dediği, ne etkide bulunduğu ve nasıl anlam yarattığıdır. Burada önemli olan sözcelemede öznenin kendisidir. Sözün anlamsal içeriği öznenin dili kullandığı bağlamdır. Nihayetinde, anlam yaşadığımız bu toplumsal yapı içinde oluşur, sabitlenir ve değişir. Sözün bildirdiği yer, zaman, bağlam ve anlam ilişkisine yönelmek ise söylem çözümlemesidir. Söylem çözümlemesinin konusu ise sözün çıkardığı anlam devinimleridir.

Feminist söylemin belirlenme durumlarına ilişkin en önemli ipucu toplumsal koşullarda saklıdır. Feminist düşüncenin oluşumuna ilişkin söylem çözümlemesi aracılığıyla cevap bulmak için söylemin hem belirlenme, hem değişim yönüyle bakmak gerekir. Aslında feminist söylemde anlamin belirlenmesine ulaşmak büyük resme bakmakla ilgilidir. Geçmişin ve şimdinin hedefleri ve gündemleri, gelecekte "olacaklarla" karşılaştırıldığında belirlenebilecektir(Ahmed, 2009, s.173). Burada toplumsalın söylemsel olana dönüşme sürecine dikkat etmelidir. Fairclough söylemin, toplumsal dünyayı inşa ettiği, bununla birlikte diğer toplumsal pratikler tarafından inşa edildiğini ileri sürer. Dolayısıyla, söylem toplumsal olarak inşa edici olduğu kadar toplumsal olarak inşa edilendir (Fairclough ve Wodak, 1997, s.258). 1980'li yıllarda feminist söylem toplumsal olanı inşa ederken, toplumsal pratikler tarafından da inşa edilmiştir. $\mathrm{O}$ nedenle feminist kelimesinin anlamı, içeriği, kullanım biçimindeki 
mesafe söylemi inşa eden kadar, söylemin kullanıldığı toplumsal pratikler tarafından da biçimlenmiștir. Bu çerçevede, sinemada feminist söylem toplumsallaşırken 1980'li yıllarda bu söylemin kime yöneldiği, ne dediği, ne etkide bulunduğu ve nasıl bir anlam inşa ettiği bu çalışmanın temel konusudur.

Burada dikkat edilmesi gereken husus, var olan toplumsal bağlamın feminist söylemle kurduğu ilişkidir. Sancar (2014, s.112) anlamı belirleyen şeyin toplumsallık içinde söylemin anlamı ile toplumsal çıkarların birlikte belirleme süreci olduğunu ve bunun çatışmalı bir durum olduğunu belirtir. Nihayetinde feminist söylem kadınların toplum içindeki konumuna ve haklarına odaklanırken bunu geleneksel yapının ve ataerkil toplum söylem yapısının yarattığı sabitlemelere karşı ileri sürer. Feminist söyleminin rastlantısıllğına bakılması, feminist söylemin sınırlarının belirlenmesi, feminist söylemin devreye girişteki koşulların belirlenmesi, feminizmi konuşan kişilerin bazı kurallara uymaya zorlanması feminist söylemin oluşma koşullarını belirleyen toplumsal düzlemde ortaya çıtığı görülür. Feminist söylem 1980'lerin siyasi ortamında ideolojik olanın içinde oluşmuştur. Toplumsal düzlemdeki ideolojik bağlam, kadına ilişkin sözün anlamını belirlemiş ve her söz zamanla söylemi yaratmıştır. Bu kapsamda, feminist düşüncenin, sinemada kimliklere ve göstergelere, dergilerde başlıklar ve fotoğraflara söylemlerle yansıması gibi, kadın hareketinin henüz başında olunduğu 1980 döneminde, Atıf Yılmaz'ın filmlerini de diğer toplumsal dinamiklerle bir arada düşünmeyi gerektirir. Bu bütüncül bakış, dönem filmlerini daha iyi anlama olanağı sunarken, 1980'li yıllarda kadınların yaşamlarındaki sorunlarını ikincil kılan ve değersizleştirilen yapıları da görmeyi sağlayacaktır.

Çalışma, feminist söylemin toplumsalı biçimlendirirken toplumsal pratikler tarafından inşa edildiği tezinden hareketle Atıf Yılmaz filmlerinden Bir Yudum Sevgi (Atıf Yılmaz, 1984) filmi merkezinde, 80 'li y1lların sinema dergisi olan Videosinema dergisi ve o y1lları tanımlamakta akademik feminist çalışmalarda kullanılan "mahcup feminizm" nitelemesi bir arada ele alınacaktır. Bu amaçla, öncelikle Türkiye akademisinde 1980'li yıllardaki feminist söyleme, Şirin Tekeli'nin oluşturduğu kuramsal çerçeve kapsamında bakılacaktır. Bu kuramsal çerçevede Tekeli'nin özne olarak kendini kurma biçimi ve kadının önündeki engeller değerlendirilecektir. Daha sonra Bir Yudum Sevgi (Atıf Yılmaz, 1984) filmindeki feminist söylemin inşası, filmdeki kadın özne "Aygül" merkezinde, dönemdeki feminist bakış açısıyla birlikte incelenecektir. Videosinema dergisi 5. sayısında ise Bir Yudum Sevgi (Atıf Yilmaz, 1984) filminin hikayesinin çıkış kişisi olan "Şengül" ile karşılaşma, Hale Soygazi'nin ve Latife Tekin' in feminist özne olarak kuruluşundaki sınırlar, dergideki yapıcı ve dönüştürücü söylemsel stratejiler kapsamında değerlendirilecektir.

\section{Feminist Söylemin Toplumsalla Kuruluşunda Mahcup Feminizm Yılları}

Dünyada küresel ekonomide kapitalizmin hakim olduğu 80’li yıllar, Türkiye'de bir çok toplumsal değişimin yaşandığı yıllardır. Sosyolojik olarak toplumda güçlü bir aile yapısı varken, kadın-erkekilişkilerinin geleneksel değerlerleyönlendirildiği evlilik kurumu veataerkil yapının izleri söz konusudur (Tanilli 2006, s.133). 1980 yılındaki askeri darbe ve devamında yaşanan askeri yönetim o yıllarda derin izler bırakmıştır. Kırel (2010) seksenli yılların sinema üretiminin de kabuk değiştirdiği bu ironik ortamda arabesk filmler, kadınları merkezine alan filmler ve güldürü filmlerinin dikkat çektiğini söyler. Bu dönem Türkiye'sinde kadınların, daha önceki yıllardan daha bilinçli biçimde toplumdaki konum ve kimliklerini sorguladıkları görülür. 1980 öncesi kadın hakları ve feminist anlayışı olmakla birlikte, 1980'lerde on yıllık bir gecikmeyle de olsa batıdaki yükselişinden sonra Türkiye'de de feminizm akademik alana 1970'ler ve 1980'ler boyunca klasik akademik disiplinlerin altında kendine özgü bir çalışma konusu ve alanı olarak kadın sorunları adı altında oluşur. Bu gelişim zaman içinde disiplinlerarası bir akademik çalışma alanı olarak kadın çalışmaları ya da giderek toplumsal cinsiyet çalışmaları adıyla özerk bir akademik çalışma alanının ve bunun ürettiği eğitim programlarının gelişimiyle genişler. Sancar (2009) bu alanda öncü çalışmaların açtığı kapıdan 
yayılan ve derinleşen bir etki ile bugün artık konuları çeşitlenen ve anlama becerisi derinleşen bir feminist tarih çalışmaları alanına sahip olduğumuzu, akademik feminist araştırmaların var olmaya başlaması ile eril egemenliğin suskun bıraktığı kadın deneyimlerini anlama ve görünür kılma amaçlı araştırmaların sayısında hızlı bir artış gözlendiğini belirtir (Sancar, 2009). Sancar'a göre, kadın çalışmalarının akademik alanda kurucu unsurlarından olan akademik feminizm, mevcut 'bilim' anlayışı içinde kadınların yaşamlarını ve bunun içindeki sorunları görünmez, ikincil ve değersiz kılanın ne olduğunu anlama ve değiştirme çabasıdır (Sancar, 2003). Sancar'ın akademik feminizm olarak nitelendirdiği alanda çalışanları Şirin Tekeli ise teorik feministler olarak tanımlar. Tekeli'nin Duygu Asena'nın ölümü üzerine kaleme aldığı "Şirin Tekeliden Duygu İçin" (2006) başlıklı yazısında kendi gibi akademide feminist düşünce üreten akademisyenlere "biz "teorik" feministler" olarak nitelerken akademi dışı feminist düşünceye katkı sunan gazeteci ve yazar Duygu Asena'nın 1980'li yıllarda feminist düşünce için önemli bir kilometre taşı olduğunu belirtir. Duygu Asena 1978 yılında Türkiye'nin ilk popüler feminist kadın dergisi Kadınca' yı kurmuş ve 1987 yılında Türkiye' de en çok satanlar arasında yer alan Kadının Adı Yok romanıyla feminizmde önemli bir çığır açmıştır.

Teorik feministlerin çalıştığ 1 feminizm 1980'li yıllarda, sol kesim de dâhil, tüm siyasi gruplar tarafından aykırı bir hareket olarak görürler. Nitekim Hartman'ın (2006) dediği gibi Marksizm ve feminizm tek bir şeydir, o tek şeyde Marksizm'dir. Solun kadın sorunu anlayışında Marksizmin feminizme egemen olmasının altında yatan temel sorun kadın hareketini sosyalist devrim amacı için tehlikeli olarak görmesidir. Bu döneme ilişkin Tekeli (1989) Birikim dergisinde, "eskiyle ve Marksizm’le sancılı bir hesaplaşma deneyimi yaşayarak ve her şeyden önemlisi, kendi günlük yaşam deneyimlerimizi enine boyuna irdeleyerek, Türkiye' de patriyarka, cinsiyetçilik, erkek egemen toplum kavramlarının geçerliliğini saptadık ve yavaş yavaş feminist olduk", der. Sol gruptan feminist hareketin gördüğü bu tepkilere karşın sadece konuşulmaya başlanmış olması bile feminist hareket adına iyi bir başlangıç olmuştur. O yıllarda kuram bağlamında, kendini "feminist kuram" içinde ele alan araştırmacı ya da akademisyen sayısı da yeterli değildir. Türkiye'nin bilinen en önemli sosyoloğu Nermin Abadan Unat başkanlığında 1978 yılında "Türk Toplumunda Kadın" konulu bir sempozyum düzenlenir. Sempozyum bildirileri 1979'da basılır ve 11-13 Ocak 1980'de bir toplantı daha yapılır ve bu toplantıda birçok alanda kadınların eşitsiz konumunu iyileştirecek çözüm önerileri tartışılır. Bu toplantılar feminist teori temelinde ve o bakışla yapılmamış ancak dönemin kadın çalışmaları arasında yer almıştır. 1980'lerin depolitizasyon ortamındaki boşlukta kadınların sessiz sedasız ve iddiasız biçimde örgütlenmeye başladığı görülür. Bu dönemde dikkat çekmeden ve sakin biçimde yürütülen yeni bir kadın bilinçlenmesi hareketi ile karşılaşılır (Birkalan-Gedik, 2009). Kadınlar artık kendi kimliklerini eşlerine ya da ailelerine göre değil, işle ve toplumsal sorunlarla tanımlamaya çalışırlar. Ancak bu gruptaki kadın sayısı seçkin denilecek kadar azdır. Bu dönemin önemli özelliği; kadınların toplumsal sorunlarını tek tek kendilerinin kurtuluşuyla değil, cins olarak kadınların kurtuluşu ile sağlanacağı inançları ve dayanışmaya verilen önemdir. 1980'ler feminizmin kurumsallaşmaya başladığı dönem olup, çok açık biçimde Türkiye'de kadın, genel tartışmalarda bırakılmayıp hayatın içinde her boyutta incelenmeye başlar. Henüz akademik bir alan olmayan feminist araştırmanın temel mesele olması ise 90'l1 yılları bulacaktır. "Kimlik" ve "farklılaşma" temelinde, kadınlar hakkında kadınlar tarafından üretilen çalışmaların arttığı bu yıllarda edebiyat alanında Adalet Ağaoğlu, Ayşe Kulin ve Buket Uzuner'in kadına dair romanlar yazdıkları görülür. Özellikle Adalet Ağaoğlu'nun Bir Düğün Gecesi romanında, Aysel ve Tezel karakterleri eğitimli ve hayatlarına karar veren kadınlar portresini çizer ve topluma ters düşmeden korkmayan bu karakterler güçlü kadın kimlikler olarak romanda yer alır. Yine de bu dönem kadın "sorununun" araştırıldığı dönem olup, güçlü bir feminist sesin olmaması ve sorgulama eğiliminin eksikliği nedeniyle Şirin Tekeli tarafından "mahcup feminizm" terimi ile açıklanır (Tekeli, 1985). 1980 sonrası Türkiye Feminist Hareketi'nin öncü kadınlarından biri olan Tekeli, Mor Çatı Kadın Sığınağı Vakfı (1990), Kadın Eserleri Kütüphanesi (1990), Kadın Adayları 
Destekleme Derneği'nin (KADER) (1997) ve son olarak Kadın Hukukçuları Destekleme Vakfı'nın (KAHUDEV)(2010) kurucularından olmuştur. Tekeli ile yapılan bir söyleşide 1978 yılında tamamladığı kadınların siyasal hayata katılımıyla ilgili tezi için akademi ve yakın çevresi tarafından "Ne demek, kadın konusunda doçentlik tezi mi olurmuş!" ifadeleriyle karşılaştığını, kadın konusunda çalışmanın siyaset bilimi gibi ciddi bir konuyla örtüşmediği eleştirisini aldığını söyler (Özdemir, 2016). Ancak, bu düşünceleri önemsemediğini söyleyen ve kadınların 1980 dönemi yaşadıklarına ve toplumda var olma biçimlerine odaklanan Tekeli (1989) şu tespitlerde bulunur;

“1980’ler Türkiye'sinde kadınlar, cinsiyetleri nedeniyle toplumun, her sınıfta en ezilen kesimini oluşturuyorlardı. onlar için kabul edilebilir tek meşru yaşama biçimi evlilikti; ilkokul ötesi eğitimden kadınlar erkeklerin gerisinde kalan oranlarda yararlandırıyorlardı; her kadının doğal işi sayılan ev işi dışında bir işte çalışma hakkı kadınlar için lafta kalan bir haktı; çalışma yaşındaki kadınların ancak $1 / 3^{\prime}$ ü çalışıyordu; onların da büyük çoğunluğu (\% 80'i) ücretsiz çalışan yardımcı aile bireyi konumunda bulunmaktaydı; ücretli işte çalışanlar (\% 15) daha çok niteliksiz işlerde yığılmışlardı" (s.36).

1983'de Somut Dergisinde ilk feminist yazılar yazılmaya başlanır. Bu yazılarda da kürtaj, doğum kontrolü gibi kadının bedensel hakları, kadının çalışma hayatı, eğitim hakkı, ev içi emek gibi konuların gündeme getirildiği görülür. Bu başlıklar dönemin kadın meseleleridir ve çözüm için uğraşı gerekmektedir. Ancak henüz feminist kelimesi o dönemde tehlikeli olacağı düşünüldügüünden Somut dergisinde kullanılmaz ve 4. sayfanın başında feminist sözcügü yerine "femina" kelimesi yerleştirilir (Kovar, 2017). Feminizm ve feminist kelimelerinin açıkça kullanılamadığı bu yıllarda yayınlanan İslamcı kadın dergileri Kadın ve Aile, Mektup ve Bizim Aile'yi 1985-1988 yılları aralığında inceleyen Feride Acar (1990) bu dergilerde kadın eğitimi konusunun kadın çalışmalarından ayrı düşünüldüğünü ve kadının kamusal alandaki varlığına hoşgörü ile yaklaşılmadığını bulgular. 1980'ler Türkiye'sinde İslamcı hareketin kadının ev içindeki rollerine yoğunlaştığını belirten Acar, kamusal alanda kadının yerini sınırlandığını ve İslam dinin kuralları ile bu sınırlamalarının meşru bir zemin sağladığını belirten mesajların bu dergide yer aldığı sonucuna ulaşır. Kadını koruma içgüdüsü kadının kamusal alanda yer bulmasını engellemiştir. Tekeli'nin kadınların bedenine hakim olmadığı, erkek otoritesine boyun eğdiği bu yılların hem ekonomik ilişkiler, hem de maddi gerçeklikler olan "inançlar, normlar ve değerler" açısından kadının ezilişinin maddi koşulları olduğunu söyler. "Kadınlar bedenlerine egemen değildiler; etkin doğum kontrolü olanakları sınırlı olduğu ve kadına ilişkin değerler değişmediği için kadınlar istemedikleri kadar çok çocuk doğurmaktaydılar (yılda \% 2.5 doğurganlık hızı), ayrıca aile içinde kadın bedeni üzerinde yoğun bir şiddet uygulaması vardı; kadının erkek otoritesine boyun eğmesi gereken, kendi başına ayakta durmaktan aciz bir zavallı olduğu inancı hâlâ çok yaygın bir değer yargısıydı" (Tekeli, 1989).

Türkiye'de 1980'li yıllarda hala feminizmin gelişmemesinin yapısal ve ideolojik nedenleri olduğunu belirten Tekeli (1985) özellikle ideolojinin maddi temelinin olmamasını önemli bir kritik olarak ileri sürer. Bu temelleri oluşturmak için uğraşmak gerekecektir. Bu nedenle Tekeli, tezinden sonraki yıllarda kaleme aldığı makalesinde (Tekeli, 1985) kadın sorunlarını dört madde temelinde sayarken, aynı maddelerin feminizmin neden gelişmediği sorularına cevap verdiğini de belirtir. Çünkü maddi temeller oluşmuş olsa da toplumun sahip olduğu ekonomik, politik ve kültürel yapıdan kaynaklanan sorunlar bulunmaktadır. Feminizmin önündeki engeller aynı zamanda 1980 döneminin feminist bakışında kadına dair sınıflandırmaları da içermektedir. Bu engellerin en başına Tekeli (1985) yapısal sorunlar olarak belirttiği kapitalizmin az gelişmiş̧liği ve dolayısıyla Türkiye'de yer alan az gelişmiş ekonomik yapıyı yerleştirir. Ekonomide ve üretimde yer alan yapının getirdiği eşitsizliğe kadınlar maruz kalmakta, kırsal bölgelerde, gecekondularda kadın emeği aile içi çalışma koşullarında sömürülmekte, yeterli iş olanakları sağlayamayan sanayinin geri kalmış yapısı 
1980 döneminin ekonomik ortamını belirlemektedir. Buna bağlı olarak kadının ezilmesi kadar ezilmişliğinin bilincine varmayışı da önemli bir sorundur. Sanayinin yetersiz iş olanakları kadının ev içi ücretsiz çalışma ortamında emeğinin sömürüsünü kolaylaştırırken toplumsal yapı bu zemini destekler.

Tekeli'ye (1985) göre ekonomik temeller ve ideolojik kabuğuyla aile feminist bilincin oluşmasını engelleyen bir görüntüye sahiptir. Bu ekonomik yapıya bağlı olarak kadının aile yapısına bağımlı olması ve ailenin bu yapısı ile değişime kapalı olmasıdır. Ailenin alternatifsiz bir kurum olması ve her ne yaşanırsa yaşansın ailenin sürekliliğinin öncelemesi yine döneme ait sorunlar olarak sınıflandırılır. Aile kadın için alternatifsiz bir kurumdur ve kadın aile bireylerinin varlığ ile var olur. Gelişmeye kapalı olan o dönemdeki aile kurumu kadının tek başına yaşaması, boşanmasına imkan vermemekte, kadının özgürleşmesine kurulan yapılarla engellemektedir. Bir diğer başlık ve en önemlisi eğitim olanakları bakımından eğitimin cinsiyetler arası farklı ve eșitsiz dağılımıdır. Eğitimde cinsler arası eșitlik sadece ilkokul düzeyindedir. Ekonomik ve kültürel yapı, erkek çocuğunun okuması için fedakarlığa izin verirken kız çocuğu için gereksiz görür. Oysa feminist ideolojinin oluşması için kadınların eğitim almaları ve toplumdaki durumlarının farkına varmaları gerekir. Eğitim imkanlarından ancak küçük bir grubun bu dönemde yararlandığı görülür. Eğitime ulaşan seçkin kadınlar için ise feminizm Türkiye için gereksiz bir ideolojidir. 80 döneminde kadınlar için en meşru yaşam biçimi evliliktir. Türkiye'nin geçirdiği siyasi dönüşüm, Kemalist ideolojinin yarattığ dönüşümler, tek partili ve çok partili hayata geçişler feminist düşüncenin maddi temellerini oluşumundaki gecikmenin siyasi ideolojik yapısı içinde tanımlar. Tekeli (1985), Kemalizm ile feminizmin eş anlamlı olmasındaki yapının kadınları daha çok sahip olduklarını koruma güdüsüne yönelttiğini söyler. İslam düşüncesinin kadını evin içinde tutan yaklaşımı ve bunu benimseyen kadınların laik anlayışa karşı durmak için örtünme eğilimleri, kadının kendi için değişim taleplerinin önündeki bir başka engeldir. Elbette, bu kadar muhafazakar yapıda değişimi talep etmek ironik olurdu. Türkiye' de Kemalist ideolojiye yaslanan kadının sorunlarını devlet çözer yaklaşımına sahip feminist anlayış ve sol ideolojinin kadın sorunları meselesine "ana, fedakar kadın" söylemi ile yaklaşımı bu dönemdeki feminist düşüncenin önündeki temel engellerdir.

Şirin Tekeli'nin 1980'li yıllarda feminist düşünceye çok önemli katkıları olmuştur. Türkiye' de henüz başlangıç aşamasında olan feminizme ilişkin Tekeli ve diğer feminizme ilgisi olan akademisyenler öncelikle feminizm hakkındaki kitapları çevirerek feminist literatürü öğrendiklerini bir röportajında bahseder. Aynı zamanda feminist jargonları bu çevirilerle kendi literatürümüze katarlar. Feminizmin maddi temellerini oluşturmaya ilişkin Tekeli'nin bir röportajındaki şu sözleri önemlidir;

“Bizim, feminizmi öğrenmemiz lazım diyerek yola çıktık. Nasıl öğreneceğiz? Bir kitabı çevirerek öğrenmeye karar verdik. Herkes evindeki kitapları getirdi. İyi bir başlangıç olacağını düşündüğümüz Juliet Mitchell'in Kadınlık Durumu'nu çevireceğimiz ilk kitap olarak seçtik. Kitabı çevirirken de feminist literatürün terminolojisini öğrendik. Üzerimizde feminizmi Türkçeleştirmek sorumluğu vardı. Bu yüzden her kavramı nasıl çevireceğimiz üzerine uzun tartışmalar yaptık. Mesela, "male dominance" bu kavramlardan biriydi. Sosyolojide ataerkillik diye bir şey var fakat tamamen feminizmin atfettiği patriyarka, erkek hegemonyası içeriğinden boşaltılmış şekilde kullanılıyor. Ben itici bile gelse patriyarka kavramını kullanmamız lazım, ataerkillik dersek güme gider diye düşünüyordum. Nihayetinde kitapta patriyarka olarak çevirmeye karar verdik."(Özdemir, 2016).

Her ne kadar akademik anlamda feminist düşüncenin maddi temelleri oluşturulmak için daha sessiz sakin çalışmalar olsa da feminist düşünce edebiyat ve sinema dünyasında popüler biçimde yüksek sesle bu yıllarda konuşulmaya ve biriktirilmeye başlanır. Aynı yıllar sinemanın da değişim geçirdiği döneme denk gelir. Özellikle kadınlara ve kadınlığa 
ilişkin meselelerin ele alındığı kadın filmleri kategorisi oluşmaya başlaması da yine bu zaman diliminde gerçekleşecektir.

\section{Feminist Öznenin Sinema, Akademi ve Dergi Etrafında Bir Aradalığı ya da Aykırılı̆̆ı}

Gazeteci ve yazar Ayşe Düzkan yürütücülüğünde Ekim 2015'de “Ele güne karş1 yapayalnız; 80'ler Türk Sinemasında Kadınların Özgürlüğü" atölyesi, kadın cinselliği, cinsiyet politikaları ve sanat-siyaset ilişkisi temelinde, 1980'li yıllarda yükselen kadın özgürlüğü fikrinin sinema ve edebiyat gibi kurgusal sanatları nasıl etkilediğini tartışmaya açar. Düzkan, katılımcılara Atıf Yılmaz'ın Bir Yudum Sevgi (1984), Adı Vasfiye (1985), Mine (1985) filmleri ve Duygu Asena'nın Kadının Adı Yok (1987) romanı üzerinden politik konuların sanata yansımalarını tartışmalarına ortam yaratır. ${ }^{1}$ Amaç filmlerde anlatılan kadın özgürleşmesine daha yakından bakılırken yapılan hatalara dikkat çekmektir. Bu bakış da 80'li yıllardaki feminist düşünce ve bunun sinema ve edebiyata yansımasındaki siyaseten yapılan hataların görülmesi ile birlikte o dönemin koşulları ve sınırlılıklarına da derinlemesine bir bakış gerektiği üzerinde durulur. 1980'li yıllar kadın hareketi nihayetinde muhalif bir harekettir. Ancak muhalif olma şekli, rijit ve dönüştürücü olmaktan ziyade toplumun algılarına göre biçimlenir. Kırel'e (2010) göre seksenli yıllarda sinemada yer alan kadın temsillerinin dikkat çekici olduğu açıktır. Filmlerdeki kadın karakterlerin tüketim kültürünün yaygınlaşmasının en önemli unsuruymuşçasına sınıf atlamaya hevesli -genellikle ev kadınları- konumunda tutulmaya israrla devam edilir ve toplumsal cinsiyet temelli erkek egemen sinema sektörünün yapısı net bir biçimde fark edilebilir (Kırel, 2010).

\section{Bir Yudum Sevgi Filminde Feminist Özne Aygül}

Ataerkil söylem ya da feminist söylem, söylemin dışsal ve nesnel olması nedeniyle özneyi üretir. Anlamlar özne üzerinde harekete geçer. Öznesi kadın olan filmler yapan Atıf Yılmaz'ın Bir Yudum Sevgi (Atıf Yılmaz, 1984) filminde yaratılan söylemlerle feminist özne üretilebilmiş midir? Ağırlıklı olarak kadın filmleri çeken Atıf Yılmaz, Bir Yudum Sevgi filmiyle, 21. Antalya Film Şenliğinde en iyi film, en iyi yönetmen, en iyi özgün müzik, en iyi kadın oyuncu ve en iyi yardımcı erkek oyuncu ödüllerini alır. Atıf Yılmaz'in 1980-1989 yılları arasında çektiği on yedi filmden on üçü kadın merkezli filmler oldukları için bu yapımlar kadın filmleri olarak adlandırılır. Atıf Yılmaz, 1980'li yıllarda "kadın filmleri" olarak adlandırılan, temelinde kadını ve kadınların sorunlarını ele alan filmler yaparak Türkiye' de kadın meselesine dikkat çeken Türk sinemasının önemli bir yönetmenidir. Akademik yazında da bu nedenle çok sayıda Atıf Yılmaz başlıklı tez ve makale bulunmaktadır. Esen'in (1985) henüz filmin gösterimde olduğu yıllarda yapmış olduğu tezde Atıf Yılmaz'la yapılan görüşmede Yılmaz Bir Yudum Sevgi (Atıf Yılmaz, 1984) filmindeki Aygül için şu sözleri söyler;

“Bir kadını ele alarak o kadının kişiliğinde Türkiye' de 25-30 yıldır süren ve hala bitmemiş olan geçiş dönemini anlatıyordu. Kırsal kesimden kente akım oluyor ve onlar şehrin varoşlarına yerleşiyorlar ve orada bir kimlik arayışı başlıyor. Yani şehirle insanların uyumu, çatışması işçileşmesi, esnaflaşması, uyum sağlaması ya da sağlayamaması, geldikleri yörelerden getirdikleri birtakım törelerle çatışmaya düşmeleri, o törelere bir taraftan uymaya çalışıp, bir taraftan büyük kentteki yaşam biçiminden dolayı uyamamaları, ondan doğan çelişkiler. Film bunları anlatıyordu, bir kadının kişiliğinde"

Bu sözler kadına ilişkin ipuçlarını verir. Aslında Tekeli'nin (1985) bahsettiği feminizmin çıkmazda kalmasına neden olan meseleler bu filmin senaryosunda görülür. Öncelikle toplumsal yapı, ataerkil yapının mekan değișikliğine rağmen devam etmesi, ekonomik olarak iş̧̧ileşme ya da esnaflaşmayı göstermek filmin temel kurgusu içinde vardır. Ama filmin merkezinde eyleyen olarak Aygül karakteri vardır. Film boyunca Aygül'ün eylemleri filmin kurgusunu oluşturur.

\footnotetext{
${ }^{1}$ Gülsün Harman (2015, 19 Ekim) “Deliren Kadının Özgürlüğü https://saltonline.org/tr/1223/atolye-ele-gune-karsiyapayalniz-80ler-turkiye-sinemasinda-kadinlarin-ozgurlugu (erişim 19 Nisan 2020)
} 
Bir Yudum Sevgi (Atıf Yılmaz, 1984) filminin konusunu hatırlarsak film dört çocuklu Aygül'ün işsiz ve zayıf kişilikli kocası ile gecekondu hayatına odaklanır. Kararlı ve güçlü ve aynı zamanda güzel kadın karakterin hayatına ilişkin kararlar alabilmesi senaryoda işlenir. $\mathrm{Bu}$ kararlar sırasıyla kendine ve çocuklarına faydası olmayan kocasından ayrılmak için çocuklarını alarak evi terk etmesi kendi başına bir eve taşınması, fabrikada işe girmek için mahallenin saygın delikanlısı Cemal'den yardım istemesi, fabrikada işe başlaması, burada yeni çevreye sahip olması ve Cemal'e olan ilgisini gizlememesi ve erkeğin ilgisini yönlendiren bir kadın karakterdir. Film incelendiğinde Şirin Tekeli (1985)'nin belirttiği feminizm düşüncesi önündeki engeller Aygül'ün kendini gerçekleştirmesi ile bazı kesişimler bulunur. Aygül karakterini oynayan Hale Soygazi, Videosinema (1984, s.12) dergisinde "Ezik bir kadın değil Aygül, cinselliği olan bir kadın. Ve bunu cesurca dile getirebiliyor ki bu Yeşilçam' daki kadın tiplerine benzemiyor...Acılı günler geçiriyor ama, haklarını savunuyor, direniyor. Ben bunun kadına bakışa yeni bir boyut getirdiğine inanıyorum." derken Aygül'ün özne olmasından bahseder. 1980 sonrası Türk sinemasında kadının özne olmasına dair filmlerle karşılaşılır. Kadın tam olarak özgürleşmese de haklılığına dair, tercih yapabilmesine dair karakterler sinemada yer almaya başlar. Aslında işçilerin dünyasındaki meşru olmayan aşkı ele alan film, kadını destekleyen bir kurgu üzerine kurulsa da kadının özgürlük anlayışı bireysel alanda ve cinsellikle sinırlı kalır. Toplumsal bağlamından koparılan bu özgürlük alanı Aygül'ün fabrikada çalışmaya başlamasına denk gelir.

Kadın emeğinin ev içi değersizliği filmde görülür. Filmdeki kadın karakterlerin Aygül, komşusu ve gecekonduda yaşayan kadınlar aile içindeki ezilmişliği ve aile yapısını korumaya çalışılması görülür. Aygül ev işi yaparken, çocuklara bakarken, mutfak alışverişi için bakkala giderken, kocası evde yemeği bekleyen, kahvede oyun oynayan ya da arkadaşlarını içmek için eve getiren bir karakterdir. Aile yapısının değişmezliği ve kadının aile içindeki tanımlarıyla var olmuşluğu ile kocasından ayrıldıktan sonra Aygül'ün köyden erkek kardeşini getirmesi önemli bir göstergedir. Çünkü evden ayrılmıştır ve evinde onu koruması için bir erkeğe ihtiyaç vardır. O denklem film sonuna kadar sürer. Kadın kendini aile içindeki yapısına göre tanımlar. Kadının tek başına yaşayamayıp bu denklemi devam ettirmesi Cemal'in hayatına girmesi ile paraleldir. Evli ve dört çocuk sahibi bu kadınla yine evli ve çocuklu erkek karakter Cemal'in arasında başlayan yakınlaşmanın zamanla cinsel isteğe; bir süre sonra da aşka, sevgiye dönüşmesi anlatılır. Bu Tekeli'nin (1985) tespitlerinin filmdeki izdüşümüdür. Eğitim konusu filmde kızının ders çalışması olarak zaman zaman yansır. Ancak eğitim ya da kadının kendi bilincine varması filmin yüzeyine çıkmaz. Çok açık sesle söylenmez. Bu da bize evet güçleniyoruz ama biraz mahcubuz ifadesini verir. Dönemin feminist söyleminde de Aygül'ün yaşadığı gibi bir çekingenlik vardır. Feminist düşüncenin akademideki tespiti ile kurgusal bir film karesindeki izdüşümü burada örtüşür. Aslında toplumdaki aydınlar da feminizm konusunda henüz başlangıç aşamasındadır. Bu nedenle Aygül feminist özne olamaz. Ataerkil yapıya başkaldırdığı yer, filmde yani çocukları alıp başka bir eve taşınması ve fabrikada işe girmesi ile olur. Ancak işe girişi sağlayan yine bir erkektir ve hayatına bir başka erkeğin desteği ile devam edecektir. Toplumun meşru gördügüu aile kalıplarının içine girmesi, eğitimsizliği ve elbette bilinç eksikliği filmin çeşitli karelerinde görülür.

Film gecekondudaki yaşama odaklanır. Yoksulluk ve kadının çocukları ile baş etme çabası, çocukların top yerine bir kafatası ile oynaması, sürekli veresiye yazdırılan bakkal dükkanı, Aygül'ün sorumsuz kocası, buna karşın mahallenin, mert erkeği Cemal. Erkekler kahvehane gibi kamusal alanında görülürken, kadınlar komşu sohbetleri ve ev içi yaşam pratiklerinin gösterildiği mekanlarda yer alır. Filmin senaryosunda yoksulluk ve sorumsuz erkek karakteri varken kadın ise sorunları çözmek için çare arayandır. Burada Aygül aktif özne olmakla birlikte, sınırları çizilen bir kadın karakterdir. Bu sınırlar toplumsal yapı tarafından çizilir ve bu yapının devamını sağlayacak kadar bir özgürlük alanı yaratılır. Bu alan Aygül'ün işe girmesidir. Ancak evli bir erkekle ilişkisi bu sınırları zorlar ve filmin 
sonunda evlilik fotoğraflarının gösterilmesi de bu sınırın ancak meşru temelleri oluşturulursa mümkün olacağını görmemizi sağlar. Oysa feminist özne değiştiren, dönüştüren ve rijit olandır. Feminist söylemin sınırları Aygül'ün evi çocuklarıyla birlikte terk etmesine izin verir. Bu evden ayrılışta dahi kadın özne annedir. Çocuklarından filmin sonuna kadar ayrılmaz ve böylece anne kutsallığı söylemi de korunmuş olur. Aygül karakterinde kadının kendi kimliği ile tek başına varoluşuna izin verilmez.

\section{Videosinema Dergisinde Şengül ile karşılaşma}

Videosinema dergisi 5. sayısı 1984'de "Yeşilçam Kadına Bakıyor" teması ile çıkar. Mahcup feminizm dönemi, feminizmden bahsettiğinizde dirençlerle karşılaştığınız bir dönemdir. "Bir Yudum Sevgi Üzerine Tartışma"(1984) başlıklı yazı Aydın Sayman, Latife Tekin, Hale Soygazi, Macit Koper ve Vecdi Sayar'ın filmi değerlendirmelerini içermektedir. Yazı Bir Yudum Sevgi (Atıf Yllmaz, 1984) filminin senaristini ve oyuncuların bir araya getiren bir içerikte sunulur. Bu yazıda (1984, s.11-15) filmdeki karakterlerin yaşanmış bir hayat hikayesinde alındığı anlaşılır. Gerçek hayattaki Şengül ile burada karşılaşırız. Latife Tekin Şengül'ün hikayesini yazmak ister. Hikayede sizi çeken neydi sorusuna Tekin, “O insanların yeni bir hayat arayışları oldu. Bunun dışında o iki insanın kişilik özelliklerinden gelen ve birazcık da o dünyanın dışına çıkma ve hayatı daha temel bir biçimde değiştirme eğilimleri ağır basıyordu. Çünkü bu gecekondudaydı...bilinçli bir yönelme ya da bilinçli bir noktaya sıçrayabilecek ağırlıkta bir yönelme vardı. Bir de tabii bunların aşklarının aslında politik boyutları filan da vardı." biçiminde cevaplar. Gerçek hayatta Alpay ve Şengül, Cemal ve Aygül karakterlerine dönüştürülmüştür.

Şengül'ün hikayesi 1977'de geçer. Tekin şöyle devam eder. “Aslında ben hikayeyi düşünürken ağırlıklı olarak politik çevreye karşı bu insanların mücadelesini düşünmüştüm. $\mathrm{Bu}$ iki arkadaş öncü sayılacak nitelikte işçilerdi o dönemde. Ve bunların ikisinin ilişkisi sendika çevresinde, grev ortamında yoğun tepkilere yol açtı. Ahlaki bulunmadi. Hatta Alpay'ın sendikadan atılmasına kadar uzandı". Feminist düşünce eleştirel düşüncedir ve özünde muhalif olmayı taşır. İşçi eylemleri var olan düzene karşı yapılan grevlerle feminizm bu anlamda kesişir. Ancak 1970-80 dönemindeki sol hareket feminist düşünceyi bir bölünme olarak görür. O nedenle kadının kendi başına özne olması, hayatına karar verme yetisi olmasını desteklemez. Sol düşünce bu dönemde Şengül'ün yaşamındaki sorunları görmezden gelirken, ikincil ve değersiz kılar. Sayar yazıda "politik olarak ileri bir ortam bile bu ilişkiye iyi gözle bakmadı" derken bunu kasteder. Latife Tekin 1970'li yılların sonunda bu öyküyü yazmayı düşünmediğini çünkü anlamlandıramadığını belirtir. Bu arada Tekin, Şengül'ü maden işkolunda bir fabrikanın temsilcisi olmasını "maden işkolunda kadın temsilci sayısı azdı. O yüzden ilgimi çekti." derken kadın kimliği ile Şengül'ü aslında sabitler. Kadın kimliğine, işçi ve sendika temsilcisini eklemlemesi kolay olmamıştır. Şengül'ün kadın işçi olması, işçi hakları konusunda aktif ve evlilik dışı birliktelik olması Tekin'in ilgisini çeker. Tekin'in tanımlamalarında Şengül'ün toplumda onaylanmayan bir ilişkinin de aktörü olduğu belirtilir. Gerçek hikayedeki Şengül'ü tanımamız Tekin'in şu sözleri ile devam eder; “üç yıl kadar ilişkilerini sürdürdüler. Birlikte yaşarken bir çocukları oldu. O zaman Alpay boşanmamıştı. Çok zorluk çektiler. Çocukları öldü, parasızlıktan, hastalıktan. Sonra ikinci bir çocukları oldu. Sonra Alpay karısından boşanabildi. Ve evlendiler. 12 Eylül öncesi sade bir nikahla evlendiler." Nihayetinde gerçek hayattaki Şengül ve filmdeki Aygül sevdikleri erkeklerle evlenerek meşru bir zemini olan bir ilişkiye sahip olurlar. Şengül'ün hikayesi 1980 döneminde yaşamış gerçek bir kadının hikayesidir. Latife Tekin "Beni en çok ilgilendiren yanı buydu hikayenin. Çevrelerinde insanların tavırları sonucu bayağı yalnız kaldılar. Politik olarak da yalnız kaldılar." Oysa Tekin senaryo da bunlara yer veremediğini gerçeğinden kopuk bir hikaye ile karşılaşıldığını belirtir. Bunu da söyleminde "Gerçek hikayeden oldukça uzaklaşıldı. Bunu da yapmak gerekiyordu. Politik boyutu çıkartıldığı zaman ortada klasik bir aşk hikayesi, işte sevimli, hatta komik bulunabilecek bir hikaye kaldı elimizde" sözleri ile 
belirtirken dönemin politik ortamı ile nedenselleştirir.

Aslında senaryoda feminist söylemin sınırları daraltılmış, kadının özgürleşmesi koşulları ataerkil yapıya göre belirlenmiş ve bunun ötesinde feminizmi konuşan ve yazan Tekin'in toplum kurallarına uymaya zorlanması olmuştur ki bu da 1980 döneminde feminist söylemin koşullarını belirleyen zemin olmuştur. Toplumsal düzlemdeki ideolojik yapı kadına ilişkin anlamı ve buna bağlı olarak da söylemi yaratmıştır. O nedenle Videosinema Dergisindeki röportajda Vecdi Sayar, Latife Tekin'e “izlediğin filmle gerçek arasında nasıl bir ilişki kurabilirsin?" sorusunu yönelttiğinde “Aslında Cemal ile Aygül'ün ilişkisi Şengül'le Alpay’ın ilişkisi değil...p politik boyutlarını çıkardığımız zaman şöyle bir noktaya varmıştık: Yerleşik bir işçi yaşamı ve onların ürettikleri kültür, hiç olmazsa o olsun senaryoda. Kadın işcileşme süreci getirsin, o dünyadaki ilişkileri, mahalle ile fabrika arasındaki çelişkiyi, mahalledeki kadınlarla erkeklerin dünyasını, oradaki çelişkileri yansıtsın, bir yandan da belgesel niteliği ağır basan bir şey çıksın ortaya istedik." cevabını alır. Ama Tekin'inin de belirttiği gibi bunlar filmde ortaya çıkmaz. Çünkü feminist söylem Fairclough (1997)'ın belirttiği gibi toplumsal olarak inşa edilendir. Bu nedenle Bir Yudum Sevgi (Atıf Yılmaz, 1984) filminde kadına ilişkin söylem toplumsal yapıya göre çizilmiştir.

Oysaki gerçek hayatta Videosinema dergisindeki yazının bundan sonraki bölümünde feminist söylemin sınırları ve feminist söylemin devreye giriş koşullarını görürüz. Anlamı belirleyen şeyin toplumsallık içinde söylemin anlamı ile toplumsal çıarların birlikte belirleme süreci olduğunu ve bunun çatışmalı bir durum olduğunu söyleyen Sancar (2014, s.112)'ın belirttiği gibi, toplumsal çıkarlarla feminist söylem çatışmıştır. Feminist söylemde Aygül ve Şengül arasında önemli bir açıklık oluşur. Videosinema Dergisinin röportajında Aydın Sayman ise bunu Atıf Yılmaz sineması özelliklerine dayanarak ve genelleştirerek açıklar. "Atıf Yılmaz filmleri genellikle kadın üzerine filmlerdi, sevgi üzerine filmlerdi. Büyük kelimelerle tanımlamaya gerek yok. Kadın erkek arasındaki cinselliği de içeren sevgi üzerine yapılmış filmlerdi...Bir Yudum Sevgi özünde iki insanın her şeye karşın sevgilerini savunmalarını konu alıyor. Atıf Yılmaz "Delikan"da ve "Mine"de de aynı temalarla yaklaşmaya çalışıyor, fakat Yeşilçam’ın kalıplarına teslim oluyordu." Filmin ortaya çıkış biçimi ve kimliklerin belirlenişinde Türk Sinemasının dayattığı kalıpların neler olduğu aynı derginin Zeynep Avcı (1984, s.63) imzalı “Türk Sineması Kadına Bakıyor mu?” başlıklı yazıda ayrıntılı biçimde karşımıza çıkar. Avcı ekonomik etkenleri Yeşilçam’ın kalıplarının oluşmasında temel motivasyon olarak yorumlar. "Türk sinemasında kadına bakışı" etkileyen en önemli kişinin gişe memurunun olduğunu belirttiği yazısında ikinci etmenin ise erkek bakışının olduğunu belirtir. "Türk sinemasının kadına bakışını, gişe memurunun mesaisi ne denli etkiliyorsa, Galata Köprüsünde dolaşan 'bey'de o denli etkilemekte. Üstelik Türk sineması diye genellediğimiz yapı, ne yazık ki büyük çoğunlukla böyle“. Kadına bakışın cinsellik, fantezi ile eril bakış stratejileri yine bu dergideki yazıda eleştirel biçimde ele alınır. Kadına eril bakışla bir kalıp haline getirdiği ve sonra bu kalıbı müstehcenlikten erotizme doğru değiştirmeye çalışıldığı çeşitli kanıtlarla sunulan Avcı'nın (1984, s.64) yazısında, Atıf Yılmaz'ın kadının içinde bulunduğu kıskaçtaki çırpınışlarına bakabilmesi başlı başına zafer olarak nitelendirilirken, seks ve erotizm denildiğinde Türk sinemasında en önemli nesnenin kadın olduğu belirtilir. Yine aynı yazıda "Neyse ki sinemamızdaki ustalar (örneğin Atıf Yılmaz) imdada yetişmiş de, kadının cinselliğinden kaba-saba ölçülerde değil estetik olarak kullanımını sağlamışlar" sözleri ile kadına eril bakışın nasıl boyut değiştirerek sürdürüldüğü yazıların farklı paragraflarında görülür. Avcı, kadının önce bazı kalıplara yerleştirildiğini, sonra o kalıplar çerçevesinde erkek değerlendirilmesiyle kullanıldığını şu sözlerle vurgular; "Türk sinemasında "tip-tip" ayrılan kadınları, bugüne kadar yönetmenler har vurup harman savurmuşlar. Ama başarılı yönetmenler bu tipleri yerlerine oturtup cinsel öğenin sinema estetiği ile buluşmasını sağlamıştır...Tipler neler? "vamp kadın? (ihraç malıdır?) Aile kadını (ayrı ihraç, yarı geleneksel yerli malıdır) Kötü kadın (evrensel maldır), erotik kadın. Türk sinemasının kendine bakışını eleştirdiği yan kadınların müstehcenlik boyutundan çıkarıp 
erotik boyutta ele almasının gecikmesidir" Özellikle son cümlede belirtilen kadına bir insan bakışı ile bakılmadığı Avcı tarafından söylemsel stratejilerle kanıtlanır; kadın görüntüsünün pornografik döneminde metalaşarak sinemada bir satış aracı olarak kullanıldığı dönemlerin kapanması ile Türk sineması kadınların cinselliğini ne yapacağını şaşırmıştır. Bu nedenle derginin bir başka yazısında Pınar Kür (1984, s.18) Bir Yudum Sevgi (Atıf Yılmaz, 1984) filmi için Aygül'ün cinsel doyumsuzluğunun ilk kareden itibaren vurgulandığını belirtirken "sürahiler dolusu doyumlu-doyumsuz cinsellik var bu filmde" ifadesini kullanır.

Diğer taraftan kadın özne de kendisinin ne olduğunun, nerede olduğunun, hangi sanat dalında yerinin, tanımının ne olduğunu yeni tartışmaya başlamıştır. Burada aynı röportaj yazısında (Sayman ve diğerleri, 1984, s.14) Hale Soygazi'nin söylemleri dikkat çeker. “Kadının bu yolu seçişi sezgisel. Kadın içsel bir değişim geçirmiyor. Yaptıklarının bilincine vararak yapmiyor. Bizim anlatmak istediğimizde bu. Bu finalden sonra Aygül çok olumlu bir kişi de olabilir, çok olumsuz bir kişi de." Benzer sözler Tekin'den de gelir “..kötü şeyler üretebilecek bir potansiyele dönüşme eğilimi var diye düşünüyorum. Bu da bilinç faktörünün olmaması...kadının bütün çabaları sonucu gelip Cemal'le evlenmesi, egemen ideolojiye teslim olması" ifadeleri ile özellikle Aygül'de bilinç faktörünün olmaması vurgulanmaya çalışılır.

Videosinema dergisinde Latife Tekin (1984) tarafından cümlelerin arasında söylediği "O değişim bana kadında hoşa giden ama yabancı gelen bir şeymiş gibi geliyor...çok cesur bir şey.. ne kadının temel değişimi ne de yeni yaşam biçimini değiştirdiği gösteriliyor (s.13)" sözleri ile doğrulanır. Filmin senaryosunu yazarken Tekin'in zorlandığı yine dergideki şu cümlelerde görülür: "senaryo çok sert bir senaryoydu bence. Cesaretin ötesinde sertti. Yeşilçam diye bir şey var, ticari kalıplar var, insanların kafasında kalıplar var. Onları bir anda aşmak, değiştirmek de mümkün değil." (Sayman ve diğerleri, 1984, s.15) Tekin nihayetinde sıralanan bu nedenlerle, Atıf Yılmaz'ın senaryosunu yumuşatmasını haklı görür.

Filmin temasına ilişkin yazıda Sayman “Toplumsal önyargılara sevgi konusunda, cinsellik konusunda bir çeşit karşı çııış olarak, sevginin savunulması için doğru bir tavır getirdiği için, bunu yaparken de bize yaşamdan bir parça sunduğu için sevdim. Filmin insanları, ön plana çıkmış" ifadelerini kullanır. Bu cümle feminist söylemin sınırlarının toplumun koşullarına göre belirlendiği, kadın filmi olarak nitelendirilen filmlerde dahi toplumdaki genel geçer kurallara uyulmasının gerektiği düzlemi göstermesi bakımından ilgi çekicidir. Bu filmde, mahcup feminizmin oluştuğu teorik düşüncedeki sınırlara karşı çıkışın dayanağ aşk ve sevgi olmuştur, kadının özgürleşmesi değil. Ama bu düşüncelerin 1990'l1 yılların feminist ikliminin olgunlaşmasında temel olduğu da inkar edilemez. Bu yıllar, kadın ve erkeğin iki ayrı değer olarak temsil edildiği dönem değildir. Kadın, aile içi rolleri ile belirlenir ve ataerkil yapının koşulları içinde özgürleşmenin sınırları da çizilir.

1980'li y1llar aynı zamanda darbe sonrası süreç ve liberal dönüşümlerin yaşandığı dönemdir. Feminist anlayışın yeni doğduğu ve sinemaya sansürün yeni geldiği, sinemada dönüşümün yaşandığı bu yıllar sinemanın kadına değil, gișesine baktığı düşüncesi derginin çeşitli yazılarında da görülür. Kadın emeği, ataerkil yapının getirdiği alternatifsiz aile anlayışı ya da ideolojik yaklaşım derginin gündeminde nadiren yazılar arasına sıkışır. Ama asıl mesele sinema izleyicisini sinemaya çekebilmektir. Videosinema dergisinin kadına bakışı, kadın kimliğinden ziyade görsel bir nesneolmasıdır.Kadına dairözelliklekullanılan fotoğraflar, kadın özgürleşmesinin kadının cinsellik deneyiminde özgürleşmesi olarak söylemselleştirilmiştir. Derginin fotoğraflarına bakıldığında kapaktan itibaren, Türk sinemasının kadına bakışı ile ilgili sayfalarda kadın bedenin haz öznesi olarak kullanıldığg görülür. Tali Öngören'in aynı dergide kadının sinemadaki yıllar içindeki yerine değinen "Türk Sinemasında Kadın ve Cinsellik" (1984, s.59) başlıklı yazısında, son yıllarda Türk sinemasında kadın ve cinsellik 
yine değişmektedir. Artık seks filmleri azalmış, ama sömürülen cinsellik ve çıplaklık bu kez köyden yıllardan beri kente akan adına arabesk denilen bir toplum ve müzik türü içinde karşımıza çıkmaya başlamıştır, yorumunu yapar. Bu tür filmlerde iyice açılıp saçılan dolgun vücutlu kadınlara bolca rastlanır derken aileleri filme çekmek isteyen yapımcıların adına aile filmi dedikleri yapımların ortaya çıkışı 1980'li yıllar olur. Öngören bu durumu şu sözlerle eleştirir: "bu filmlerde anatomisini alabildiğini gözler önüne seren kadın oyuncular var. Üstelik bu gibi filmlerin öykülerinde bu tür kadınlar sevdikleri erkeklerle evlenebiliyorlar, hatta çocukları oluyor. Sonra kaçınılmaz ayrılık ve en sonunda çocuğu sayesinde yeniden birleşme...Ama aile filmi türüne uymayan cinsellik ve çıplaklık sömürüsü eşliğinde..". Aynı yazıda Mine (Atıf Yılmaz, 1982) filminde ise kadının özgürleşme çabasının övüldüğü görülür. Bu filmler arasında kadının özgürleşmesi cinsellik üzerinden anlatılırken, insanca yaşama isteği de film senaryolarında kadın anatomisi arasına sıkıştırılır. Bütün bu çerçeveden bakıldığında Videosinema dergisindeki yazılarda, Türk sinemasına kadına bakışı biçimlendiren en önemli şeyin ekonomik kaygılar olduğu, yönetmenlerin sansür ve dağıtım kanalları ile uğraşırken, aslında kadın karakterlerin varoluşunu toplumsal koşulların biçimlendirdiğine dair söylemlere rastlanmıştır. Aynı zamanda kadın da kendinin farkında değildir. Bilinç eksikliği hem yazıların içeriğinde, hem de söylemsel stratejilerde görülür. Kadın emeği ve kadın bedeni sömürüsünün kabul gördüğü bu dönemde, feminist düşüncenin keskinliğinden söz etmek için 90'lı yılları beklemek gerekir.

\section{Sonuç}

Feminist düşünce üzerine fikir üretirken ve değerlendirme yaparken dikkatli olmak zorundayız. Feminist düşüncenin tarihi ile ilgili bir metni ele almak ekstra dikkat gerektirir. Bu çalışma ile 1980 dönemindeki feminist düşünce ile sinema üretimi arasındaki toplumsal bağı ortaya koyarak, feminist düşünce ve sinema etkileşimini ortaya koymak amaçlanmıştır. Sara Ahmed (2018)'in dediği gibi bir döneme ilişkin alıntılama aynı zamanda bellektir ve o dönemdekilere minnettir. Bu düşüncelerle çalışmada feminizmin önündeki engeller Şirin Tekeli' nin belirlediği dört başlık altında incelenerek, sinemadaki ve yazınsal alandaki söylem stratejilerine bakılmıştır.

Çalışmada 1980'li dönemlerde Türkiye' de feminist bilincin oluşmaya başladığı yıllar olduğuna dikkat çekilerek, aynı bilincin sinemada kadın öznenin yaratılmasındaki sınırlara yansıması değerlendirilmiştir. Bu çalışmanın en ilgi çekici yanı Şengül'le karşılaşmak olmuştur. Latife Tekin'in hayatın içinden gözlemlediği Şengül o dönemin Akademik feminizmin yarattığı düşüncenin de ilerisindedir. Hikayeyi yazan Tekin tarafından dahi çeşitli sabitlemelerle karşılaşan kadın kimliği, filmin senaryosunda gerçek hayattaki kadın kimliği ile zaten var olamamıştır. Bu toplumsal olanın kültürel üretim biçiminde nasıl ıskalandığının da çok açık örneğidir. Akademik feminizm ekonomik, siyasi, aile yapısı ve eğitim önündeki engelleri feminizm önündeki engeller olarak saymakla birlikte, o dönemin doğası gereği toplumda yaşanan tikel örneklerden de kopuk olabileceğini göstermiştir. Bu engellerle birlikte toplumun bakış açısı hem sanata hem akademiye sirayet etmiştir. Bu nedenle akademik feminizm, dergideki söylemler ve filmin içeriği birbirini bütünleyen ve destekleyen bir haritalamayla karşımıza çıkmıştır. Özellikle dergideki söylemlerin, feminist bilinci bastırdığı söylenebilir. Çünkü aynı mahcupluk dergideki yazılarda ve filmin senaryosunda da var. Burada Sara Ahmed'i anmak gerekiyor. "Metinlerimiz bir dünyaysa feminist malzemelerden yapılması gerek. Feminist teori, teoriden kalan bir şey olmadan gündelik hayata katılan olmalı ve feminist bir yaşam getirmelidir" (2017, s. 29). Şengül tam olarak feminist bilincin farkında olmadan feminist bir özne olmayı 1980'li yıllarda başarmıştır. Ama Aygül, kendini yaratanların tahakkümünden kurtulamamıştır. Nihayetinde feminizmin önündeki en büyük engel kendi tahakkümlerimizdir. Kendi tahakkümlerimizin farkına varmadığımız takdirde geçmişte miras aldığımız birçok soruyu sormaya devam ederiz. Bu nedenle feminizmin sınırlarını, kime öne sürüldüğünü belirleyici ve bu sınırları daha da genişletici söylemsel 
içeriklere her alanda ihtiyaç vardır.

Türkiye'de feminizm tarihsel sürecinde yaşananlar ve oluşturulan söylemler ve geçmişle şimdiki karşılaşmalarımızla geleceği biçimlendireceğimize bu çalışmayla dikkat çekmek istenmiştir. Tarihsel olarak kurulan kadının özne olma halinin nasıl evirildiğini görmek lazım. Geçmişteki söylemler bugünü biçimlendirirken, bugünün söylemlerinin de geleceği biçimlendireceği sezgisi ile sinema ile feminizm ilişkisine bakarak geçmişle karşılaşmanın geleceğe sızması muhtemel beklentisi bu çalışmanın çıkış noktasıydı. Feminist söylemin akademideki sınırları ile sinema ve popüler yazınsal dergideki sınırların benzer olduğunun bulgulandığı bu çalışma, her döneme ilişkin feminist akademik düşünce ile sinema ve yazınsal metinlerdeki karşılaşmalarına ilişkin çalışmaların sayısının artması, hala günümüzde mahcupluğunu kısmen de olsa devam ettiren feminist söyleme önemli değer katacaktır. Zira Liberal, İslami, Sosyalist, Marksist, Radikal gibi birbirinden farklı feminizmlerin bulunduğu günümüzde kadın öznenin hak ettiği değere ulaşması için sinema dişil dil üretmek ve feminist söylemin sınırlarını genişletmekte çok önemli bir noktada bulunmaktadır.

\section{Kaynakça}

Abadan-Unat N. (1979) Toplumsal Değişme ve Türk Kadını. Türk Toplumunda Kadın, Nermin Abadan-Unat. (Der.) Türk Sosyal Bilimler Derneği ve Araştırma, Eğitim. İstanbul: Ekin Yayınları.

Abisel, N. (2005) Türk Sineması Üzerine Yazılar. Ankara: Phoneix Yayınları.

Acar, F. (1990) Türkiye' de İslamcı Hareket ve Kadın-Kadın dergileri ve Bir Grup Üniversite Öğrencisi Üzerinde Bir İnceleme. Şirin Tekeli (Der.) Kadın Bakış Açısından 1980’ler Türkiye'sinde Kadınlar, (s. 69-87) içinde. İstanbul: İletişim yayınları.

Ahmed, S. (2009). Bu Öteki ve Başka Ötekiler. Cogito, 58, 173-192.

Ahmed, S. (2017). Feminist Bir Yaşam Sürmek. Beyza Sümer (Çev.) Aydaş. İstanbul: Sel yayincilik.

Avcı, Z. (1984). Türk Sineması Kadına Bakıyor mu? Videosinema, Kasım 5, 63-66.

Butler, A. (2011). Film Çalışmaları. Ali Toprak (Çev.). İstanbul: KalkedonYayıncılık.

Birkalan-Gedik, H. (2009). Türkiye' de Feminizmi ve Antropolojiyi Yeniden Düşünmek: Feminist Antropoloji Üzerine Eleştirel Bir Deneme. Cogito, 58, 285-338.

Esen, Ş.(1985). Atıf Yılmaz Batıbeki ve Genç Türk Sineması. (Yüksek Lisans tezi). YÖKSİS veri tabanından erişildi.

Fairclough, N ve Wodak, R. (1997). Critical Discourse Analysis. T. A. van Dijk (Ed.). Discourse as Social Interaction (258-284) içinde. London: Sage yay.

Harman, G. (2015, 19 Ekim). Deliren Kadının Özgürlüğü. Salt Galata. Erişim adresi: https:// saltonline.org/en/2043/deliren-kadinin-ozgurlugu?blog 
Hartman, H. (2006). Marksizm'le Feminizm'in Mutsuz Evliliği. Gülşat Ayşen (Çev.). İstanbul: Agora yayınevi

Kellner, D. (1996). Media Culture, Cultural studies, identity and politics between the modern and the postmodern. London: Routledge.

Kırel, S. (2010). Ertem Eğilmez'in Namuslu Filminden Hareketle Seksenlerin Toplumsal Alanında ve Popüler Sinemasında Egemen Değerlerini ve Sinemadaki Temsillerini Sorgulamak" Kurgu Online International Journal of Communication Studies, 2, s.1-29.

Kovar, Nehir (2017, 8 Mart). Muhakkak Bir Femina Olsun. T24 Bağımsız Internet Gazetesi Erişim Adresi: https://t24.com.tr/k24/yazi/muhakkak-bir-femina-olsun,1122

Kuhn, A. (1982). Women's Pictures: Feminism and Cinema. London: Routledge and Kegan Paul.

Kür, Pınar (1984). Bir Yudum Sevgi. Videosinema, Kasım 5, s.18

Mulvey, L. (1997). Görsel Haz ve Anlatı Sineması. N. Abisel (Çev.) 25. Kare: Sinema Kültür Dergisi. Ekim/Aralık, 38- 46.

Öngören, M. T. (1984). Türk Sinemasında Kadın ve Cinsellik. Videosinema, Kasım 5, Kasım, 58-66.

Özdemir, E. (2016, 30 Haziran). Şirin Tekeli ile Söyleşi: Karı Kuvvetlerinden Feminist Harekete. 5Harfliler. Erişim adresi: http://www.5harfliler.com/sirin-tekeli-ile-soylesi-karikuvvetlerinden-feminist-harekete/

Ryan, M ve Kellner, D. (2010). Politik Kamera. Elif özsayar (Çev.). İstanbul: Ayrıntı yayınları.

Sayman, A., L. Tekin, H. Soygazi, M. Koper ve V. Sayar (1984). Bir Yudum Sevgi Üstüne Tartışma. Videosinema, 5, Kasım, 11-15.

Sancar, S. (2003). Üniversitede Feminizm? Bağlam, Gündem ve Olanaklar. Toplum ve Bilim, Güz, 97. 164-182.

Sancar, S. (2009). Türkiye'de Feminist Çalışmaların Siyaset Bilimine Etkisi. İ.Ü Siyasal Bilgiler Fakültesi Dergisi, 40, Mart, 119-132. 
Sancar, S. (2014). İdeolojinin Serüveni, Yanlış Bilinç ve Hegemonya Söylemi. 3.bsk. İstanbul: İmge Kitapevi.

Smelik, A. (2008). Feminist Sinema ve Film Teorisi ve Ayna Çatladı. D. Koç (Çev.). İstanbul: Agora Kitaplığı.

Tanilli, S. (2006). Ne Olursa Olsun Savaşıyorlar. İstanbul: Alkım yayınları.

Tekeli, Ş. (1985). Türkiye' de Feminist İdeolojinin Anlamı ve Sinırları Üzerine. Kadınlar İçin: Yazılar (1977-1987). İstanbul: Alan Yayıncılık, s. 307-325

Tekeli, Ş. (1989). 80'lerde Türkiye'de Kadınların Kurtuluşu Hareketinin Gelişmesi. Birikim Dergisi, 3, Temmuz, 34-41

Tekeli, Ş.(2006, 01 Ağustos). Şirin Tekeliden Duygu İçin. Bianet. Erişim adresi: https://m. bianet.org/bianet/kadin/83117-sirin-tekeliden-duygu-icin

Videosinema Dergisi (1984). Say1.5, Kasım

Yılmaz, E. (2004). Sinema ve İdeoloji İlişkileri Üzerine. Sinemasal, 10, 23-35.

Yılmaz, A. , Kavur, Ö. ve Deveci, S. (Yapımc1) \& Yılmaz, A. (Yönetmen) (1984) Bir Yudum Sevgi (Sinema Filmi) Türkiye: Delta Film, Yeşilçam Film.

Wood, R. (1992). Ideology, Genre, Auteur. G. Mast, M. Cohen, L. Braudy (Ed.). Film Theory and Criticism-Introductory Readings (475-485) içinde. 4. basım. London: Oxford University Press, 